\title{
BEBERAPA ASPEK BIOLOGI UDANG JERBUNG (Penaeus merguiensis) DI PERAIRAN PANTAI CILACAP JAWA TENGAH
}

\author{
Suradi Wijaya Saputra, Djuwito, Ayu Rutiyaningsih* \\ Jurusan Perikanan, Fakultas Perikanan dan Ilmu Kelautan, Universitas Diponegoro \\ Jl. Prof. H. Soedharto, SH. Tembalang Semarang 50275 Telp/Fax (024) 76480685
}

\begin{abstract}
Abstrak
Eksploitasi udang $P$. merguiensis dengan alat tangkap jaring arad diduga terus meningkat ditandai dengan meningkatnya produksi dalam tiga tahun terakhir. Penangkapan yang berlebihan dapat mengancam kelestariannya. Tujuan dari penelitian ini yaitu untuk mengkaji aspek-aspek biologi seperti komposisi hasil tangkapan, distribusi hasil tangkapan, struktur ukuran, ukuran pertama tertangkap $\left(\mathrm{L}_{50 \%}\right)$, panjang infinity $(\mathrm{L} \infty)$, nisbah kelamin, tingkat kematangan gonad (TKG), sifat pertumbuhan, dan faktor kondisi. Selain itu, membuat konsep pengelolaan sumberdaya perikanan udang $P$. merguiensis. Metode yang digunakan dalam pengambilan sampel yaitu metode survei dengan sistematik random sampling. Sampel udang diambil secara proposional yaitu sekitar $10 \%$ dari total hasil tangkapan. Hasil penelitian menunjukkan bahwa ukuran pertama tertangkap $\left(\mathrm{L}_{50 \%}\right)$ panjang karapas $43 \mathrm{~mm}$. Panjang infinity (L $\left.\infty\right)$ udang $P$. merguiensis betina panjang karapas $63,58 \mathrm{~mm}$ dan udang $P$. merguiensis jantan 60,42 mm. Perbandingan nisbah kelamin jantan dan betina $1: 1,61$. Udang $P$. merguiensis didominasi oleh TKG I. Pertumbuhan udang $P$. merguiensis jantan bersifat allometrik negatif yaitu pertambahan panjang lebih cepat daripada pertambahan beratnya, dikarenakan nilai b sebesar 2,626. Udang $P$. merguiensis betina memiliki sifat pertumbuhan isometrik yaitu pertambahan panjang selaras dengan pertambahan berat, dikarenakan nilai b sebesar 3,105 . Faktor kondisi udang $P$. merguiensis jantan sebesar 1,152 dan betina 2,051, sehingga udang Jerbung betina lebih montok dibandingkan udang $P$. merguiensis jantan. Udang $P$. merguiensis layak ditangkap pada ukuran yang melebihi $\mathrm{L}_{50 \%}$ yaitu panjang karapas $>$ $43 \mathrm{~mm}$.
\end{abstract}

Kata kunci : Udang Jerbung, Aspek Biologi, Perairan Cilacap

\begin{abstract}
Abstrak
Exploitation of P. merguiensis shrimp with arad fishing gear was allegedly growing up characterized by an increased production in the last three years. Overfishing could threaten the sustainability of resource. The objectives of this research were to know biological aspect such as composition of the catch, distribution of the catch, size of structure, first of length capture $\left(L_{50 \%}\right)$, infinity length $(L \infty)$, sex ratio, gonad maturities $(T K G)$, growth, and condition factor. In addition, was made management fisheries $P$. merguiensis shrimp resource. The method used in this reseach was survei method with sistematic random sampling. Shrimp samples were taken in proportion is about $10 \%$ of the total fishing catch. The results showed that the first of length capture $\left(L_{50 \%}\right)$ carapas length $43 \mathrm{~mm}$. Infinity length $(L \infty)$ of $P$. merguiensis female was 63,58 $\mathrm{mm}$ and $P$. merguiensis male was 60,42 $\mathrm{mm}$. Sex ratio of P. merguiensis shrimp male and female was $1: 1,61$. Gonad maturities of P. merguiensis shrimp was dominated on level 1. Growth of P. merguiensis male was negative allometric that is long increase faster than weight, because $b$ value was 2.626 Growth of P. merguiensis female was isometric that is the length of tune with weight, because b value was 3,105. Condition factor of P. merguiensis male was 1,152 and female was 2,051, so P. merguiensis shrimp female more plumpness better than male. P. merguiensis shrimp decent arrested at a size that exceeds $L_{50 \%}$ that is lengh carapas $>43 \mathrm{~mm}$.
\end{abstract}

Key words : Jerbung shrimp, Biological aspects, Cilacap water 


\section{Pendahuluan}

Perairan Cilacap merupakan perairan yang dalam dan curam dengan dasar perairan umumnya pasir, tetapi dengan adanya beberapa sungai yang bermuara di perairan tersebut, maka di beberapa daerah mempunyai dasar berlumpur. Hal ini mengakibatkan perairan Cilacap dan sekitarnya menjadi perairan yang subur dengan kandungan sumberdaya alam yang melimpah, terutama sumberdaya perikanan termasuk sumberdaya udang (Rahayu, 2000).

Potensi udang di daerah Cilacap sangat tinggi terutama genus Penaeus (Subagyo, 2005). Di antara genus Penaeus, udang Jerbung (Penaeus merguiensis) merupakan jenis udang yang banyak dimininati oleh masyarakat, karena kandungan daging pada udang ini sangat banyak hampir $75 \%$ dari berat tubuhnya, sehingga penangkapan terhadap udang jenis ini cukup tinggi. Meningkatnya penangkapan udang $P$. merguiensis dengan alat tangkap jaring arad akan mengancam kelestarian udang $P$. merguiensis di perairan Cilacap. Berdasarkan data dari Dinas Kelautan dan Perikanan Kabupaten Cilacap (2012), produksi udang P. merguiensis di perairan Cilacap meningkat dari tahun ke tahun. Produksi tahun 2010 sebesar $72.520 \mathrm{~kg}$, tahun 2011 sebesar $114.715 \mathrm{~kg}$ dan tahun 2012 sebesar $307.200 \mathrm{~kg}$.

Tingginya intensitas penangkapan udang Jerbung di perairan Cilacap memungkinkan perkembangan stok terhambat. Selain itu, dapat menyebabkan perubahan terhadap aspek biologi, yang mengakibatkan terancamnya kelestarian populasi udang Jerbung. Oleh karena itu pengelolaan sumberdaya udang Jerbung di perairan Cilacap perlu dilakukan, untuk menjaga kelestarian sumberdaya udang tersebut.

Penelitian ini bertujuan untuk Mengkaji aspek biologi udang $P$. merguiensis yaitu komposisi hasil tangkapan, distribusi hasil tangkapan, struktur ukuran, ukuran pertama tertangkap $\left(\mathrm{L}_{50 \%}\right)$, panjang infinity $(\mathrm{L} \infty)$, nisbah kelamin, tingkat kematangan gonad (TKG), sifat pertumbuhan, dan faktor kondisi. Membuat konsep pengelolaan sumberdaya perikanan udang $P$. merguiensis di perairan Cilacap.

\section{Materi Dan Metode Penelitian}

\section{A. Materi Penelitian}

Materi penelitian adalah udang $P$. merguiensis yang tertangkap di perairan pantai Cilacap yang di daratkan di tempat pelelangan ikan (TPI) yaitu TPI Menganti Kisik, TPI Lengkong, TPI Kemiren dan TPI Tegal Katilayu. Alat yang digunakan dalam penelitian ini yaitu cool box yang digunakan untuk tempat menyimpan dan mengawetkan udang. Jangka sorong dengan ketelitian $0,01 \mathrm{~mm}$ yang digunakan untuk mengukur panjang udang $P$. merguiensis. Timbangan elektrik ketelitian 0,001 gram untuk mengukur berat udang P. merguiensis. Buku identifikasi untuk megidentifikasi jenis udang yang didapatkan. Lup (kaca pembesar) digunakan untuk memperbesar bagian dari tubuh udang agar mempermudah dalam pengamatan. Satu set alat sectio untuk membedah udang dalam identifikasi tingkat kematangan gonad. Sterofoam digunakan untuk alas dalam pengukuran morfometrik. Jarum pentul digunakan untuk membuat titik atau penanda dalam pengukuran morfometrik. Alat tulis digunakan untuk mencatat hasil penelitian.

B. Metode Penelitian

Penentuan lokasi, pengambilan sampel, dan pengumpulan data

Pengambilan sampel udang $P$. merguiensis dilakukan pada TPI dimana banyak nelayan yang mendaratkan udang hasil tangkapan arad di daerah tersebut. Berdasarkan informasi yang ada, terdapat 4 TPI pengambilan sampel yaitu TPI Menganti Kisik, TPI Lengkong, TPI Kemiren, dan TPI Tegal Katilayu. Pemilihan TPI-TPI ini dikarenakan dapat mewakili keseluruhan hasil tangkapan udang $P$. merguiensis dengan jaring arad yang ada di perairan pantai Cilacap. Sampel udang diambil secara sistematik random samping atau proporsional yaitu sekitar $10 \%$ dari total hasil tangkapan salah satu perahu pada setiap TPI. Sampel yang didapatkan dipilah-pilah sesuai dengan jenis dan ukuranya. Pengambilan sampel setiap 1 bulan sekali selama 4 bulan mulai Oktober 2012 - Januari 2013.

\section{Analisis Data}

\section{Struktrur Ukuran}

Perhitungan struktur ukuran meliputi panjang maksimal, panjang minimal, panjang rata-rata udang, dan panjang yang sering muncul (modus). Dihitung dengan statistik deskriptif dan disajikan dalam bentuk grafik.

\section{Ukuran Pertama Tertangkap}

Ukuran rata-rata udang tertangkap didapatkan dengan cara memplotkan frekuensi kumulatif dengan setiap panjang udang, sehingga akan diperoleh kurva logistik baku, dimana titik potong antara kurva dengan $50 \%$ frekuensi kumulatif adalah panjang saat 50\% udang tertangkap

Panjang Infinity $(\mathbf{L} \infty)$

Panjang infinty $(\mathrm{L} \infty)$ merupakan ukuran rata-rata panjang udang pada umur yang sangat tua. Menurut Pauly (1984) dalam Saputra (2009), perhitugan panjang infinty adalah sebagai berikut:

Keterangan

$$
\mathrm{L} \infty=\mathrm{L}_{\max } / 0,95
$$

$\mathrm{L}_{\max }=$ Panjang maksimum (mm)

\section{Hubungan Panjang Berat}

Menurut Effendi (2002), analisis hubungan panjang berat menggunakan persamaan sebagai berikut : $\mathrm{W}=\mathrm{aL}{ }^{\mathrm{b}}$ 
Keterangan :

$\mathrm{W}=$ berat tubuh $($ gram $)$

$\mathrm{L}=$ panjang karapas $(\mathrm{mm})$

$\mathrm{a}=$ Intercept

$\mathrm{b}=$ Slope

Bentuk linier dari persamaan tersebut adalah: $\log \mathrm{W}=\log \mathrm{a}+\mathrm{b} \log \mathrm{L}$

\section{Faktor Kondisi}

Menurut Effendie (2002), perhitungan faktor kondisi untuk $b \neq 3$ memenuhi persamaan dibawah ini :

$$
\mathrm{K}=\mathrm{W} / \mathrm{aL}^{\mathrm{b}}
$$

Keterangan : $\quad \mathrm{K}=$ Faktor kondisi

$\mathrm{W}=$ Berat $($ gram $)$

$\mathrm{L}=$ Panjang total $(\mathrm{mm})$

\section{Nisbah Kelamin}

Nisbah kelamin dihitung dengan cara membandingkan jumlah udang jantan dengan jumlah udang betina dengan menggunakan uji chi-square (Hadi dalam Suparjo, 2005).

Keterangan :

$$
\mathrm{X}^{2}=\Sigma\left[(\mathrm{fo}-\mathrm{fh})^{2} / \mathrm{fh}\right]
$$

fo = Frekuensi udang jantan dan betina yang teramati.

fh $=$ Frekuensi harapan, yaitu frekuensi udang jantan ditambah udang betina dibagi dua.

$\mathrm{X}^{2}=$ Sebuah nilai bagi peubah acak $\mathrm{x}^{2}$ yang sebaran penarikan contohnya menghampiri sebaran.

\section{Hasil dan Pembahasan}

\section{Distribusi dan Komposisi Udang $P$. merguiensis}

Distribusi hasil tangkapan udang $P$. merguiensis di beberapa TPI tersaji dalam Gambar 1 dan 2.

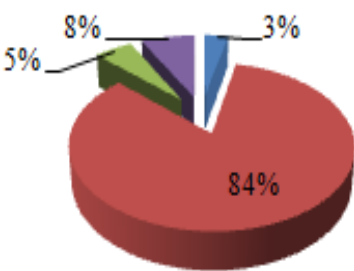

(a)

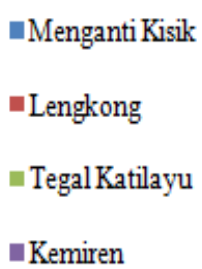

- Kemiren

Gambar 1. a. Distribusi Hasil Tangkapan Udang P. merguiensis Berdasarkan DKP 2012 (4.196,2 kg)

b. Distribusi Hasil Tangkapan Udang P. merguiensis Berdasarkan Penelitian(5,69 kg).

Berdasarkan distribusi hasil tangkapan udang P. merguiensis tahun 2012 diketahui bahwa, TPI Lengkong mendominasi hasil tangkapan yaitu 84\%. Selain itu TPI Kemiren mempunyai hasil tangkapan sebesar 8\% dan TPI Tegal katilayu memiliki hasil tangkapan sebesar 5\%. TPI Menganti Kisik memiliki hasil tangkapan yang paling sedikit yaitu sebesar $3 \%$. Berdasarkan hasil tangkapan selama penellitian TPI Kemiren memiliki hasil tangkapan lebih besar diantara TPI-TPI yang lain yaitu 45\%. Sedangkan hasil tangkapan udang $P$. merguiensis paling sedikit terdapat pada TPI Menganti Kisik yaitu sebesar 4\%. TPI Tegal Katilayu memiliki hasil tangkapan sebesar 35\% dan TPI Lengkong memiliki hasil tangkapan sebesar $16 \%$.

Komposisi hasil tangkapan udang Penaeid di perairan Cilacap tersaji dalam Gambar 2.

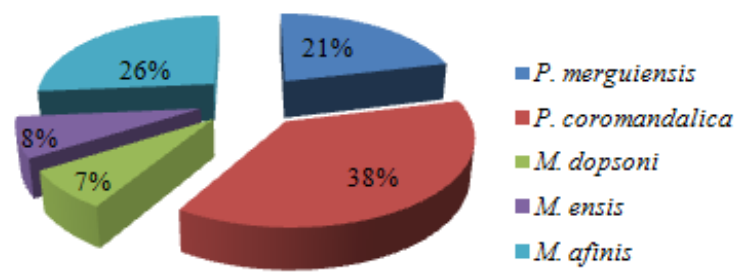

(a)

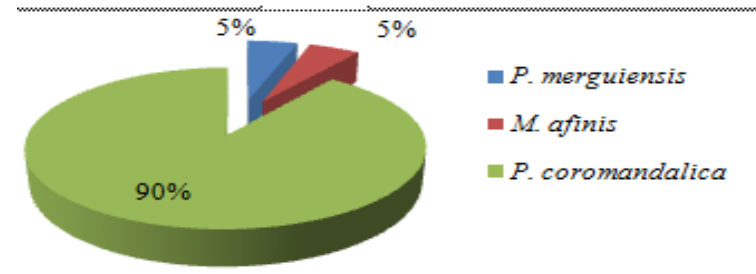

(b)

Gambar 2. a. Komposisi Tangkapan Udang Penaeid Selama Penelitian $(26,84 \mathrm{~kg})$. b.Komposisi Tangkapan Udang Penaeid Tahun 2012 (84.164,4 kg).

Berdasarkan komposisi tangkapan udang Penaeid selama penelitian di perairan Cilacap total hasil tangkapan sebesar $26,84 \mathrm{~kg}$, tangkapan terbesar yaitu $P$. coromandalica sekitar $38 \%$. Hasil tangkapan terbesar kedua setelah $P$. coromandalica yaitu $M$. afinis sebesar $26 \%$. Selain itu hasil tangkapan udang yang lain yaitu $P$. merguiensis sebesar 
$21 \%$, M. ensis sebesar 8\% dan M. dopsoni sebesar 7\%. Sedangkan komposisi tangkapan tahun 2012 total hasil tangkapan udang sebesar $84.164,4 \mathrm{~kg}, P$. coromandalica mendominasi hasil tangkapan sekitar $90 \%$. Udang Jerbung $(P$. merguiensis) dan M. afinis memiliki hasil tangkapan yang sama besar yaitu $5 \%$.

\section{Struktur Ukuran Udang $P$. merguiensis}

Struktur ukuran panjang udang $P$. merguiensis setiap sampling disajikan dalam bentuk grafik pada Gambar 3.

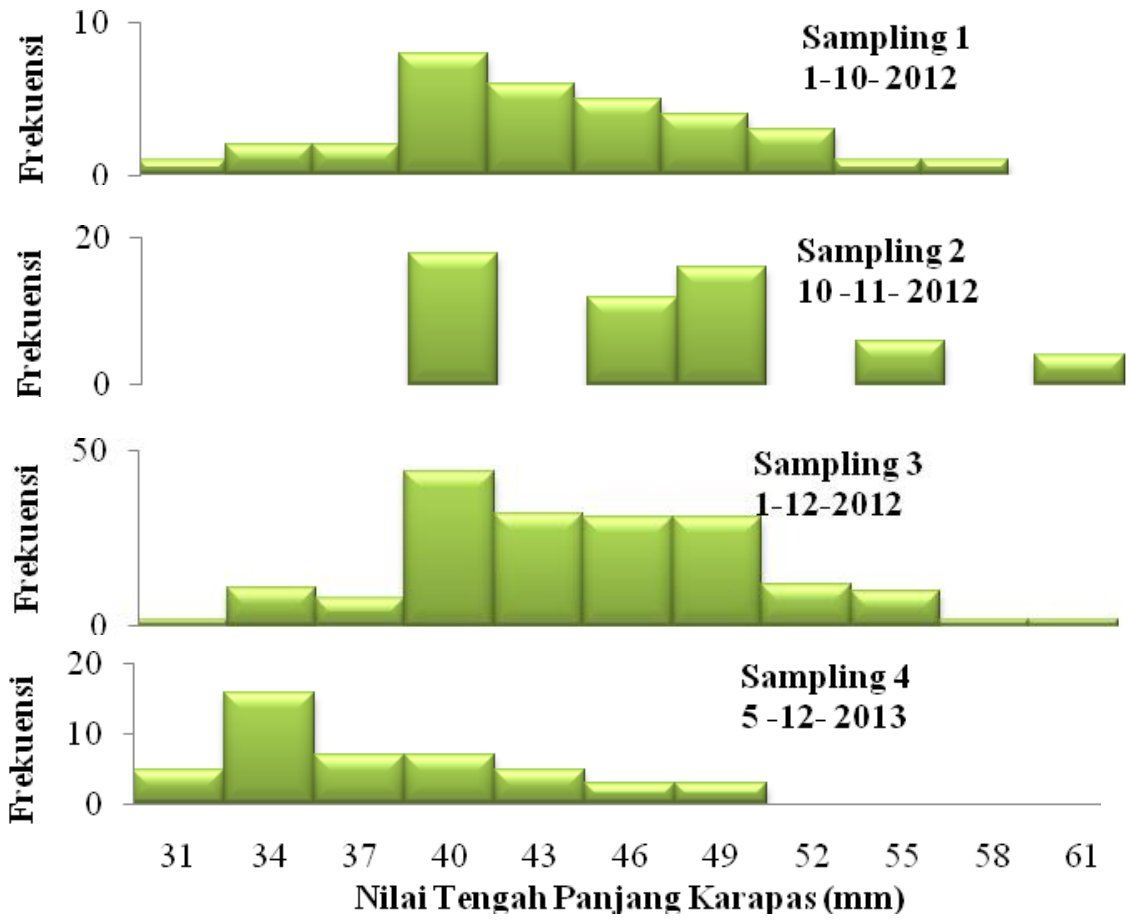

Gambar 3. Struktur Ukuran Udang P. merguiensis Setiap Sampling (Oktober 2012- Januari 2013)

Dari grafik struktur ukuran udang P. merguiensis (Gambar 3) terlihat bahwa, selama sampling pertama (1 Oktober 2012) sampai sampling ketiga (1 Desember 2012), modus panjang karapas udang P. merguiensis tetap yaitu 40 $\mathrm{mm}$. Sampling keempat (5 Januari 2013) didapatkan modus panjang karapas $34 \mathrm{~mm}$. Terjadi pergeseran modus karapas sebesar $6 \mathrm{~mm}$ yaitu dari $40 \mathrm{~mm}$ menjadi $34 \mathrm{~mm}$.

\section{Panjang Infinity $(\mathrm{L} \infty)$}

Panjang infinity $(\mathrm{L} \infty)$ merupakan ukuran rata-rata panjang udang pada umur yang sangat tua. Panjang infinity $(\mathrm{L} \infty)$ udang $P$. merguiensis selama penelitian tersaji pada tabel 1.

Tabel 1. Panjang Infinity (Lo) Udang P. merguiensis di Perairan Cilacap

\begin{tabular}{cccc}
\hline No & Jenis Kelamin & $\begin{array}{c}\text { Rata-Rata Panjang } \\
\text { Maksimun }(\mathrm{mm})\end{array}$ & $\begin{array}{c}\text { Panjang Infiniti }(\mathrm{mm}) \\
(\mathrm{L} \infty)\end{array}$ \\
\hline 1 & Betina & 60,4 & 63,579 \\
2 & Jantan & 57,4 & 60,421 \\
\hline
\end{tabular}

Hasil perhitungan panjang infinity (Lo) udang P. merguiensis betina di perairan Cilacap yaitu sebesar $63,579 \mathrm{~mm}$, sedangkan udang $P$. merguiensis jantan didapatkan hasil sebesar $60,421 \mathrm{~mm}$.

\section{Ukuran Pertama Kali Tertangkap $\left(\mathbf{L}_{\mathrm{c} 50 \%}\right)$} Gambar 4.

Perhitungan ukuran rata-rata udang Jerbung yang tertangkap selama penelitian di perairan Cilacap tersaji dalam 


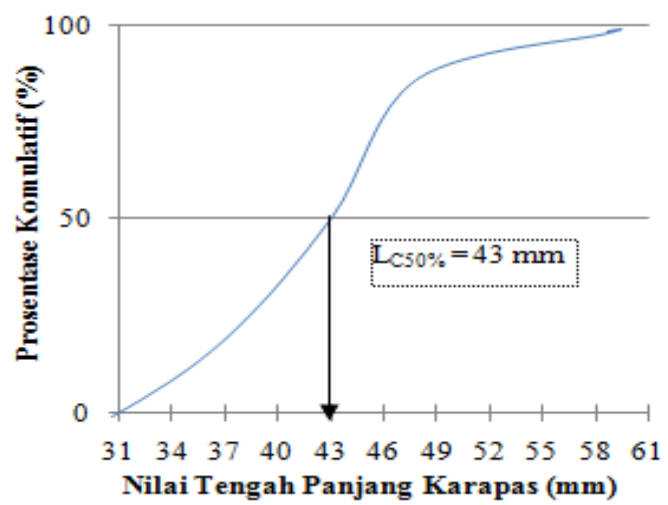

Nisbah Kelamin

Gambar 4. Grafik Ukuran Pertama Tertangkap $\left(\mathrm{L}_{50 \%}\right)$ Udang $P$. merguiensis

Hasil penelitian menunjukkan perbandingan udang P. merguiensis disajikan Gambar 5.

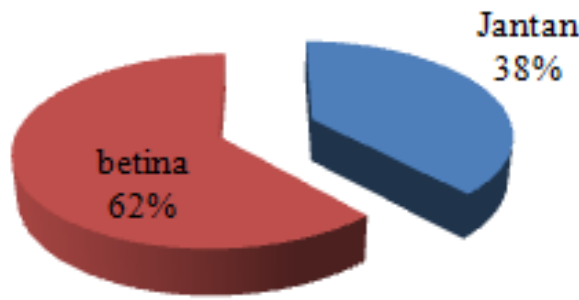

Gambar 5. Perbandingan Nisbah Kelamin Udang P. merguiensis Jantan dan Betina

Dari hasil penelitian dilakukan terhadap udang P. merguiensis sebanyak 319 ekor. Udang P. merguiensis yang diteliti terdiri dari 197 ekor udang betina dan 122 ekor udang jantan. Berdasarkan perhitungan nisbah kelamin didapatkan rasio perbandigan udang $P$. merguiensis jantan dan betina sebesar $1: 1,61$.

\section{Tingkat Kematangan Gonad}

Hasil pengamatan tingkat kematangan gonad udang P. merguiensis betina dan jantan tersaji pada Tabel 2.

Tabel 2. Tingkat Kematagan Gonad Udang P. merguiensis Betina

\begin{tabular}{cccccccc}
\hline \multirow{2}{*}{$\begin{array}{c}\text { Sampling } \\
\text { Ke }\end{array}$} & I & II & III & IV & V & Jumlah \\
\cline { 2 - 6 } I & 14 & 2 & 0 & 0 & 0 & 16 \\
II & 22 & 9 & 2 & 0 & 0 & 34 \\
III & 103 & 10 & 5 & 0 & 0 & 118 \\
IV & 30 & 0 & 0 & 0 & 0 & 30 \\
\hline
\end{tabular}

Hasil tingkat kematangan gonad udang $P$. merguensis pada sampling pertama didapatkan TKG tingkat I sebesar $87,5 \%$, tingkat II sebesar $12,5 \%$. Sampling kedua didapatkan TKG tingkat I sebesar $64,71 \%$, tingkat II sebesar $26,47 \%$, TKG tingkat III sebesar 5,88\%. Sampling ketiga didapatkan TKG tingkat I sebesar 87,29\%, tingkat II sebesar 8,47 dan TKG tingkat III sebesar 4,24\%. Sampling keempat hanya ditemukan udang P. merguiensis pada TKG tingkat I. Berdasarkan data tersebut banyak udang $P$. merguiensis dengan TKG tingkat I yang mendominasi hasil tangkapan.

\section{Faktor Kondisi}

Hasil perhitungan nilai faktor kondisi udang P. merguiensis tersaji pada Tabel 3.

Tabel 3. Nilai Faktor Kondisi Udang P. merguiensis di Perairan Pantai Cilacap

\begin{tabular}{lccc}
\hline Jenis Kelamin & Rata-Rata L $(\mathrm{mm})$ & $\begin{array}{c}\text { Rata-Rata W } \\
(\mathrm{gr})\end{array}$ & Faktor Kondisi $(\mathrm{Kn})$ \\
\hline Betina & 43,355 & 16,701 & 2,051 \\
Jantan & 44,861 & 18,205 & 1,152 \\
\hline
\end{tabular}

Berdasarkan data di atas didapatkan nilai fakor kondisi dari udang $P$. merguiensis betina dan jantan berbeda yaitu sebesar 2,051 dan 1,152. Hal ini menujukkan bahwa udang $P$. merguiensis betina lebih montok dibandingkan udang $P$. merguiensis jantan.

\section{Hubungan Panjang Berat}

Hubungan panjang berat udang Jerbung jantan dan betina selama penelitian tersaji pada Gambar 6 . 


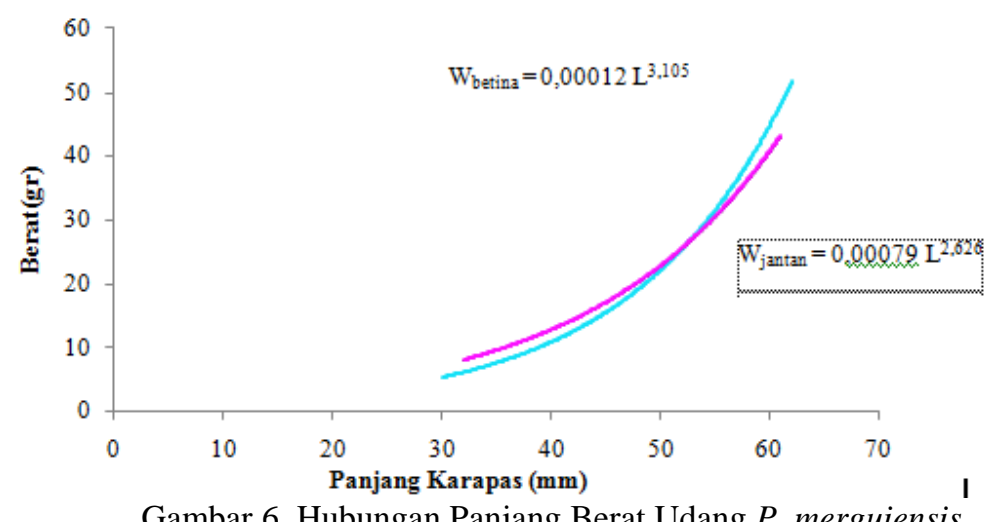

Berdasarkan pengujian terhadap nilai b dengan t-test, untuk udang $P$. merguiensis jantan didapatkan hasil bahwa $\mathrm{t}$ hitung $>\mathrm{t}$ tabel, berarti tolak Ho. Hal ini berarti sifat pertumbuhan dari udang $P$. merguiensis jantan allometrik negatif. Pertumbuhan allometrik negatif yaitu pertambahan panjang udang $P$. merguiensis lebih cepat daripada pertambahan beratnya. Sedangkan pengujian nilai b dengan t-test untuk udang $P$. merguiensis betina didapatkan hasil bahwa t hitung $<$ t tabel,

berarti udang $P$. merguiensis betina memiliki sifat pertumbuhan isometrik. Pertumbuhan isometrik yaitu pertambahan panjang selaras dengan pertambahan berat.

\section{Pembahasan \\ Distribusi Hasil Tangkapan Udang $P$. merguiensis}

Berdasarkan distribusi hasil tangkapan udang $P$. merguiensis di perairan Cilacap. Udang P.merguiensis ditemukan di semua TPI yang dijadikan tempat penelitian. Dari data tersebut distribusi udang $P$. merguiensis banyak terdapat di TPI Kemiren, kemudian TPI Tegal Katilayu dan TPI Lengkong. Udang P. merguiensis jarang di temukan di TPI Menganti Kisik. Jika dibandingkan dengan data Dinas Perikanan tahun 2012 udang P. merguiensis banyak ditemukan di TPI Lengkong. Terjadinya perbedaan distribusi antara data hasil penelitian dan data dari DKP tahun 2012 diduga disebabkan oleh, penelitian hanya dilakukan empat bulan dan kemungkinan bisa terjadi fluktuasi distribusi udang $P$. merguiensis di bulan-bulan selanjutnya. Selain itu, TPI Lengkong merupakan TPI yang besar dan banyak kapal nelayan yang mendaratkan hasil tangkapan di TPI ini. Jumlah keseluruhan kapal yang aktif di TPI lengkong sekitar 155 kapal, sedangkan TPI Kemiren sekitar 55 kapal. Menurut Purba (1991), perairan Cilacap memiliki dasar lumpur dan berpasir sehingga banyak ditemukan udang P. merguiensis di perairan ini. Menurut Gunaisah (2008), udang $P$. merguiensis menyukai perairan yang lumer (soft), biasanya terdiri dari campuran pasir dan lumpur. Menurut (Sjahrir, 2001) udang $P$. merguiensis dewasa dapat ditemui hingga jarak $15 \mathrm{~km}$ dari pantai sampai kedalaman 15 - $35 \mathrm{~m}$.

Menurut Naamin dalam Subagyo (2005), distribusi udang P. merguiensis di perairan Indonesia meliputi perairan laut yang dangkal dengan terkonsentrasi di sepanjang pantai barat Sumatera (Meulaboh, Silboga, Air Bangis), Selat Malaka, pantai timur Sumatera mulai dari sebelah utara sampai teluk Lampung di sebelah selatan, Kalimantan (barat, tengah, selatan dan timur), Sulawesi selatan, Teluk Bintuni, Kepulauan Aru, Maluku, Irian Jaya (Laut Arafuru). Pantai utara, pantai selatan Pulau Jawa yaitu di Penanjung Pangandaran, Teluk Penyu Cilacap, Barung, Granjangan, Karang Bolong, Gombong sampai selatan Yogyakarta dan Pacitan.

Komposisi hasil tangkapan Udang Penaeid selama penelitian di Perairan Cilacap didominasi oleh $P$. coromandalica. Udang $P$. merguiensis hanya ditemukan sebesar $21 \%$, selain itu hasil tangkapan yang lainya yaitu M.afinis, M. ensis dan M. dopsoni. Hasil ini sesuai dengan data dari Dinas Kelautan dan Perikanan 2012, menunjukkan bahwa $P$. coromandalica mendominasi hasil tangkapan udang Penaeid. Hal ini bisa terjadi dikarenakan alat tangkap arad lebih cocok digunakan untuk menangkap P. coromandalica dibandingkan dengan P. merguiensis.

\section{Struktur Ukuran Udang $P$. merguiensis}

Struktur ukuran panjang udang $P$. merguiensis yang tertangkap dengan arad di perairan Cilacap, memiliki modus panjang karapas $40 \mathrm{~mm}$. Pada sampling keempat terjadi pergeseran karapas dari $40 \mathrm{~mm}$ menjadi $36 \mathrm{~mm}$. Hal ini diduga terjadi perubahan stok pada sampling keempat. Ukuran panjang karapas terkecil yang ditemukan selama penelitan yaitu ukuran $31 \mathrm{~mm}$ dan panjang karapas terbesar yaitu $61 \mathrm{~mm}$.

Berdasarkan penelitian Suman et al., (1996), di perairan Cilacap menemukan ukuran panjang karapas terkecil sebesar $29 \mathrm{~mm}$ dan terbesar 53,55 mm. Penelitian Melmambbessy (2011), di Laut Arafura menemukan ukuran panjang karapas terkecil sebesar 17,8 mm dan terbesar 67,1 mm. Hasil penelitian Mudhifasari (2009), di perairan Bandengan Kendal mendapatkan ukuran panjang karapas terkecil sebesar 17,6 mm dan terbesar 51,6 mm. Suman et al., (1991), dalam penelitianya di perairan Sumba Nusa Tenggara Timur menemukan ukuran panjang karapas terkecil sebesar 15,8 mm dan terbesar 32,3 mm. Berdasarkan uraian tersebut ukuran udang P. merguiensis di Perairan Cilacap Lebih besar dibangkan dengan perairan lainya. 


\section{Ukuran Pertama Tertangkap $\left(\mathrm{L}_{50 \%}\right)$ P. merguiensis}

Ukuran pertama tertangkap $\left(\mathrm{L}_{50 \%}\right)$ udang $P$. merguiensis di Perairan Cilacap pada ukuran panjang karapas 43 $\mathrm{mm}$. Hasil ini tidak jauh berbeda dengan dengan modus udang $P$. merguiensis selama penelitian pada panjang karapas $40 \mathrm{~mm}$. Berdasarkan penelitian Saputra et al., (2007), di Segara Anakan menemukan udang P. merguiensis pertama tertangkap pada ukuran panjang karapas $18 \mathrm{~mm}$. Mudhifasari (2009), dalam penelitianya di perairan Bandengan Kendal mendapatkan ukuran pertama tertangkap pada panjang karapas 28,1 mm. Berdasarkan penelitian Apriliyani (2012), di perairan Tanjung Rusa Belitung menemukan ukuran pertama tertangkap pada panjang karapas $51 \mathrm{~mm}$. Suman et al., (1994), dalam penelitianya di perairan Demak menemukan ukuran pertama tertangkap pada panjang karapas 27,5 mm. Berdasarkan uraian tersebut diketahui bahwa ukuran pertama tertangkap $\left(\mathrm{L}_{50 \%}\right)$, udang $P$. merguiensis di perairan Cilacap mempunyai ukuran cukup besar dibandingkan dengan perairan yang lainya.

Ukuran pertama kali tertangkap udang $P$. merguiensis $\left(\mathrm{L}_{50 \%}\right)$ yaitu $43 \mathrm{~mm}$. Jika dibandingkan dengan setengah dari panjang infinity $(\mathrm{L} \infty)$, ukuran pertama kali tertangkap tidak boleh kurang dari setengah dari panjang infinity (L $\infty)$. Hal ini didukung oleh Saputra (2009), menyatakan bahwa ukuran pertama tertangkap idealnya tidak lebih kecil dari 0,5 x L $\infty$. Setengah dari panjang infinty $(\mathrm{L} \infty)$ yaitu $31,789 \mathrm{~mm}$, sehingga ukuran udang $P$. merguiensis pertama kali tertangkap lebih dari setengah panjang infinity $(\mathrm{L} \infty)$. Hal ini menunjukkan bahwa udang yang tertangkap termasuk udang yang berukuran cukup besar. Jika ukuran rata-rata tertangkap kurang dari setengah panjang infinity $(\mathrm{L} \infty)$ maka udang kecil.

Besarnya ukuran udang dapat disebabkan oleh berbagai hal. Perbedaan ukuran tersebut terjadi akibat adanya perbedaan kondisi ekologis perairan, seperti, salinitas, suhu, arus, dan ketersediaan makanan (Anggraeni, 2001).

\section{Panjang infinity $(\mathrm{L} \infty)$ P. merguiensis}

Berdasarkan data panjang karapas diperoleh panjang infinity $(\mathrm{L} \infty)$ untuk udang $P$. merguiensis betina pada panjang karapas 63,579 $\mathrm{mm}$ dan udang $P$. merguiensis jantan pada panjang karapas 60,421 mm. Dari data tersebut udang $P$. merguiensis betina dapat tumbuh mencapai ukuran panjang karapas maksimal 63,579 $\mathrm{mm}$ dan udang $P$. merguiensis jantan pada panjang karapas 60,421 mm. Berdasarkan penelitian Saputra et al., (2007), di Segara Anakan mendapatkan nilai Lo sebesar 37,5 mm. Suman et al., (1994), dalam penelitianya di perairan Demak mendapatkan nilai L $\infty$ sebesar 62,5 mm. Menurut Naamin dalam Saputra et al., (2005), udang P. merguiensis di Laut Arafura memiliki panjang infinity $(\mathrm{L} \infty)$ sebesar $50,2 \mathrm{~mm}$. Berdasarkan uraian tersebut udang $P$. merguiensis di perairan Cilacap dapat mencapai ukuran maksimal lebih besar daripada perairan lain.

\section{Nisbah Kelamin}

Hasil perhitungan nilai nisbah kelamin antara udang $P$. merguiensis jantan dan betina sebesar $1: 1,61$. Perbandingan udang $P$. merguiensis betina lebih besar dibandingkan dengan jantan. Populasi udang $P$. merguiensis betina hampir dua kali lipat dari populasi udang P. merguiensis jantan. Populasi udang P. merguiensis jantan lebih sedikit dibandingkan betina dikarenakan, udang $P$. merguiensis jantan akan mati lebih awal. Menurut Darmono (1991), udang $P$. merguiensis jantan memiliki umur yang pendek, sehingga menjadi salah satu penyebab semakin lama udang betina jumlahnya lebih banyak daripada udang jantan. Menurut Saputra et al, (2009), apabila jantan dan betina seimbang atau betina lebih banyak dapat diartikan bahwa populasi tersebut masih ideal untuk mempertahankan kelestarianya.

\section{Tingkat Kematangan Gonad}

Secara umum tingkat kematangan gonad udang $P$. merguiensis di Perairan Cilacap, didominasi oleh TKG tingkat I (belum matang) yaitu sebesar $85,35 \%$. Udang P. merguiensis yang dikatakan matang gonad apabila sudah mencapai TKG tingkat III. Hal ini juga didukung oleh Motoh dalam Melmambbessy (2011), udang betina yang matang gonad adalah udang yang gonadnya telah berkembang mencapai TKG III. Berdasarkan penelitian sedikit ditemukan udang $P$. merguiensis yang matang gonad mencapai TKG III. Udang P. merguiensis betina yang matang gonad mencapai TKG III berkisar antara $3,56 \%$. Sedikit ditemukan udang P. merguiensis yang matang gonad, hal ini diduga karena alat tangkap yang digunakan dalam penangkapan. Arad beroperasi di daerah pinggiran pantai yaitu sekitar 1-5 mill dari pantai, sedangkan pemijahan udang $P$. merguiensis berada di tengah laut. Hal ini diduga karena nelayan melakukan penangkapan di perairan pantai, sehingga bukan daerah pemijahan udang $P$. merguiensis.

Penelitian dilakukan pada bulan Oktober sampai Januari dalam waktu penelitian yang singkat belum dapat digunakan untuk menentukan waktu pemijahan. Waktu pemijahan dapat ditentukan apabila melakukan penelitian kurang lebih 1 tahun. Menurut Naamin dalam Adi (2007), udang P. merguiensis mengalami pemijahan sepanjang tahun dan mencapai puncaknya pada bulan Januari, April, Agustus, dan November. Sedangkan pemijahan terendah terjadi pada bulan Februari dan Oktober. Puncak pemijahan udang P. merguiensis setiap daerah berbeda-beda. Perbedaaan terjadinya puncak pemijahan kemungkinan dipengaruhi oleh faktor lingkungan seperti curah hujan, salinitas dan suhu.

Hasil penelitian Adisusilo dalam Suman et al., (1993), di perairan Cilacap diketahui $\mathrm{L}_{\mathrm{m} 50 \%}$ udang $P$. merguiensis sebesar 39,59 mm. Penelitian Suman et al., (1995), di perairan Demak menunjukkan $\mathrm{L}_{\mathrm{m} 50 \%}$ udang P. merguiensis pada panjang karapas 39,7 mm. Berdasarkan penelitian Suman et al., (1993), di perairan Kutai menunjukkan bahwa pertama 
kali matang gonad panjang karapas 29,8 mm. Penelitian Melmambblessy (2011), di perairan Arafura ukuran pertama kali matang gonad pada panjang karapas $60,264 \mathrm{~mm}$.

Meskipun udang $P$. merguiensis yang tertangkap selama penelitian memiliki ukuran lebih dari $0,5 \times$ L $\infty$, tetapi pada ukuran tersebut udang belum matang gonad. Banyaknya udang yang tertangkap sebelum matang gonad, akan mengancam kelestarian seumberdaya udang $P$. merguiensis di perairan Cilacap.

Menurut Anggraeni (2001), ukuran udang saat pertama kali matang gonad tidak selalu sama. Perbedaan ukuran tersebut terjadi akibat adanya perbedaan kondisi ekologis perairan. Kematangan gonad udang dipengaruhi oleh dua faktor yaitu faktor dalam dan faktor luar. Faktor dalam antara lain spesies, umur, dan ukuran. Sedangkan faktor luar yang mempengaruhi antara lain suhu, arus dan curah hujan.

\section{Sifat Pertumbuhan Udang $P$. merguiensis}

Hubungan panjang dan berat udang merupakan salah satu parameter yang dapat digunakan untuk menganalisis pola pertumbuhan suatu kelompok udang yang berguna dalam kegiatan pengelolaan perikanan. Berdasarkan pengujian terhadap nilai b terjadi perbedaan sifat udang $P$. merguiensis jantan dan betina. Udang $P$. merguiensis jantan memiliki sifat pertumbuhan allometrik negatif, yaitu pertambahan panjang lebih cepat daripada pertambahan beratnya. Sedangkan udang $P$. merguiensis betina sifat pertumbuhan isometrik, yaitu pertambahan panjang selaras dengan pertambahan berat. Perbedaan pertambahan berat udang $P$. merguiensis jantan dan betina berkaitan dengan umur udang. Selain itu udang $P$. merguiensis betina mempunyai kemampuan yang lebih baik untuk beradaptasi dengan lingkungan dan mengasimilasi makanan menjadi daging dibandingkan udang $P$. merguiensis jantan. Berdasarkan kurva hubungan panjang karapas dan berat individu, terlihat bahwa pertumbuhan panjang sangat cepat pada udang muda, dan sebaliknya pertambahan berat sangat lambat. Pada udang dewasa pertambahan panjang melambat dan pertambahan berat semakin cepat.

Menurut Murni (2004), semakin tua umur udang maka pertambahan berat akan lebih besar dibandingkan pertambahan panjangnya, sedangkan pada udang muda pertambahan panjang lebih besar daripada pertambahan berat. Hal tersebut berarti bahwa pada umur tertentu, pertambahan berat akan lebih cepat dari pertambahan panjangnya dan saat mencapai tingkat kedewasaan tertentu, akan mencapai titik dimana udang tidak mengalami perubahan panjang. Menurut Anggraeni (2001), kecepatan tumbuh sejalan dengan jumlah dan kualitas makanan yang dimakan dan kemampuan untuk mengasimilasi makanan menjadi daging.

\section{Faktor Kondisi Udang P. merguiensis}

Udang $P$. merguiensis yang terdapat di perairan Cilacap memiliki nilai faktor kondisi sebesar 2,051 untuk betina dan 1,152 untuk jantan. Hal ini menujukkan bahwa udang P. merguiensis betina lebih montok dibandingkan udang Jerbung jantan. Berdasarkan penelitian Setiyoso (2006), udang P. merguiensis di perairan Kebumen memiliki faktor kondisi untuk jantan dan betina sebesar 1,153 dan 1,187. Penelitian Mudhifasari (2009), di perairan Kendal menujukkan faktor kondisi jantan dan betina sebesar 1,547 dan 1,743. Berdasarkan uraian tersebut udang P. merguiensis di perairan Cilacap memiliki kemontokan lebih baik dibandingkan perairan lainya. Menurut Saputra (2009), nilai Kn tidak berarti apa-apa jika dilihat sendiri sebagai angka tunggal. Jika dibandingkan dengan individu lainya atau kelompok atau ukuran dengan ukuran lain yang berasal dari berbagai lokasi yang berbeda.

\section{Pengelolaan Udang $P$. merguiensis di Perairan Cilacap}

Penangkapan udang $P$. merguiensis dengan jaring arad di perairan Cilacap akhir-akhir ini yang semakin meningkat, perlu diimbangi dengan pengelolaan yang optimal. Salah satu usaha yang dapat dilakukan yaitu dengan cara memberikan kesempatan terhadap udang $P$. merguiensis untuk tumbuh dan memijah, sehingga kelestarian dapat terjaga.

Arad merupakan alat tangkap yang tidak selektif, dengan mesh size yang sangat kecil sehingga tingkat selektifitas alat tangkap juga rendah. Akibatnya banyak udang yang belum layak tangkap tertangkap oleh arad. Pemanfaatan udang $P$. merguiensis yang tidak optimun, cenderung terjadi pemborosan sumberdaya serta mengancam kelestarianya. Diduga laju eksploitasi udang P. merguiensis di perairan Cilacap sangat tinggi, sehingga diperlukan pengaturan terhadap penangkapan di perairan tersebut. Salah satunya dengan menggunakan alat tangkap yang selektif, dengan ukuran mesh size yang tepat. Ukuran yang seharusnya boleh ditangkap yaitu ukuran yang melebihi $\mathrm{L}_{50 \%}$, yaitu pada panjang karapas $>43 \mathrm{~mm}$.

. Udang P. merguiensis mengalami pemijahan sepanjang tahun dan mencapai puncaknya pada bulan Januari, April, Agustus, dan November, sehingga pada bulan-bulan ini penangkapan terhadap udang P. merguiensis harus dikurangi. Selain pengaturan ukuran mata jaring dan waktu penangkapan, pengaturan tentang pembatasan jumlah alat tangkap yang beroperasi dan pembatasan volume penangkapan juga perlu dilakukan. Pengaturan seperti ini akan tetap menjaga kelestarian stok udang $P$. merguiensis di perairan Cilacap.

\section{Kesimpulan \\ Kesimpulan}

Berdasarkan hasil penelitian yang telah dilakukan dapat diambil kesimpulan sebagai berikut :

1. Beberapa aspek biologi udang P. merguiensis yaitu:

a. Ukuran $\mathrm{L}_{50 \%}$ udang $P$. merguiensis yang tertangkap yaitu memiliki panjang karapas $\pm 43 \mathrm{~mm}$.

b. Panjang Infinity untuk udang $P$. merguiensis jantan $63,579 \mathrm{~mm}$. dan betina sebesar $60,421 \mathrm{~mm}$. 
c. Nisbah kelamin udang $P$. merguiensis jantan dan betina selama penelitian $1: 1,61$

d. Udang P. merguiensis yang tertangkap di perairan Cilacap didominasi TKG tingkat I.

e. Udang $P$. merguiensis jantan memiliki sifat pertumbuhan allometrik negatif sedangkan udang $P$. merguiensis betina isometrik.

f. Faktor kondisi Udang P. merguiensis betina sebesar 2,051 dan jantan 1,152 artinya udang P. merguiensis betina lebih montok di bandingkan jantan.

2. Konsep pengelolaan untuk udang $P$. merguiensis di perairan Cilacap yaitu dengan memberikan kesempatan terhadap udang muda untuk tumbuh dan memijah, dengan memperbesar ukuran mata jaring yang digunakan. Ukuran udang $P$. merguiensis seharusnya layak ditangkap pada ukuran yang melebihi $\mathrm{L}_{50 \%}$ yaitu pada ukuran panjang karapas $>43$ mm. Pembatasan jumlah alat tangkap yang beroperasi, waktu penangkapan dan pembatasan volume penangkapan hal ini dilakukan untuk menjaga kelestarian udang $P$. merguiensis.

\section{Daftar Pustaka}

Anggraeni, D. 2001. Studi Beberapa Aspek Biologi Udang Api-Api (Metapenaeus monoceros) di Perairan Sekitar Hutan Lindung Angke Kapuk, Jakarta Utara. [Skripsi]. Fakultas Perikanan dan Ilmu Kelautan, Institut Pertanian Bogor, Bogor, 81 hlm.

Apriliyani, N. F. 2012. Studi Tentang Udang Penaeid yang Tertangkap dengan Jaring Trammel di Perairan Desa Tanjung Rusa Kabupaten Belitung. [Skripsi]. Fakultas Perikanan dan Ilmu Kelautan, Universitas Diponegoro, Semarang, $89 \mathrm{hlm}$.

Darmono. 1991. Budidaya Udang Penaeus. Kanisius, Yogyakarta.

Effendie, M. I. 2002. Biologi Perikanan. Yayasan Pustaka Nusatama, Yogyakarta.

Gunaisah, E. 2008. Sumberdaya Udang Penaeid dan Prospek Pengembangan di Kabupaten Sorong Selatan Propinsi Irian Jaya Barat. [Disertasi]. Sekolah Pascasarjana, Institut Pertanian Bogor, Bogor, 248 hlm.

Melmambblessy, E.H.P. 2011. Ukuran Pertama Kali Matang Gonad Udang Penaeus merguiensis De Man (1988) di Laut Arafura Pada Distrik Naukenjerai Kabupaten Merauke. J. Agrikan UMMU, 4(2):75-81.

Mudhifasari, F.D. 2009. Beberapa Aspek Biologi dan Potensi Pemanfaatan Udang Jerbung (Penaeus merguiensis de Man) di Perairan Bandengan Kabupaten Kendal. [Skripsi]. Fakultas Perikanan dan Ilmu Kelautan, Universitas Diponegoro, Semarang, $87 \mathrm{hlm}$.

Murni, I. 2004. Kajian Tingkat Kematangan Gonad Udang Galah (Macrobrachium rosenbergii de Man) di Muara Sungai Kapuas Pontianak Kalimantan Barat. [Disertasi]. Sekolah Pascasarjana, Institut Pertanian Bogor, Bogor, $79 \mathrm{hlm}$.

Rahayu, F. 2000. Kondisi Gelombang dan Pengaruhnya Terhadap Pergerakan Sedimen di Perairan Pantai Yogyakarta Cilacap pada Bulan April - Mei 1999. [Skripsi]. Fakultas Perikanan Dan Ilmu Kelautan, Institut Pertanian Bogor, Bogor, $94 \mathrm{hlm}$.

Saputra, S.W., S.Sukimin, M. Boer, R. Affandi, dan D.R. Monintja. 2005. Aspek Reproduksi dan Daerah Pemijahan Udang Jari (Metapenaeus elegans de Man, 1907) di Laguna Segara Anakan Cilacap Jawa Tengah. J. Ilmu Kelautan. 10 (1) : 41-49.

Saputra, S. W. dan Subiyanto. 2007. Dinamika Udang Jerbung (Penaeus merguiensis de Man 1997) di Laguna Segara Anakan Cilacap Jawa Tengah. J. Ilmu Kelautan, 12(3):157-166.

Saputra, S.W. 2009. Dinamika Populasi Ikan. Universitas Diponegoro. $199 \mathrm{hlm}$.

Saputra, S. W., P. Soedarsono dan G.A. Sulistyawati. 2009. Beberapa Aspek Biologi Ikan Kuniran (Upeneus spp.) di Perairan Demak. J. Saintek Perikanan. 5(1):1-6.

Setiyoso, M.O. 2006. Potensi dan Tingkat Pemanfaatan Udang Jerbung (Penaeus merguiensis de Man) yang di Daratkan di TPI Kabupaten Kebumen. [Skripsi]. Fakultas Perikanan dan Ilmu Kelautan, Universitas Diponegoro, Semarang. $91 \mathrm{hlm}$.

Subagyo, W. 2005.Status Penangkapan Udang Jerbung (Penaeus Merguiensis de Man) di Perairan Cilacap dan Sekitarnya Serta Usulan Pengelolaanya. [Disertasi]. Pasca Sarjana Sekolah Pascasarjana, Institut Pertanian Bogor, Bogor, 248 hlm .

Suman, A., Iskandar, dan B. Sarjana. 1991. Aspek Biologi, Penangkapan dan Ekonomi Perikanan Udang di Perairan Sumba Timur, Nusa Tenggara Timur. J. Perikanan Laut, 57:119-129.

Suman, A., M. Rijal dan Manadiyanto. 1993. Jenis Hubungan Panjang Berat, Ukuran Matang Gonad dan Potensi Perikanan Udang di Perairan Kutai Kalimantan Timur. J. Perikanan Laut, 81:76-83.

Suman, A., M. Rijal dan Yulianti. 1994. Biologi dan Dinamika Populasi Udang Jerbung (Penaeus merguiensis de Man) di Perairan Demak, Jawa Tengah. J. Perikanan Laut, 87: 10-21.

Suman, A. 1996. Penelitian Beberapa Aspek Biologi Udang Jerbung (Penaeus merguiensis) di Perairan Cilacap Jawa tengah. J. Dinper, 11(33):35-41.

Suparjo, M.N. 2005. Potensi Udang Dogol (Metapenaeus ensis) di Kabupaten Kebumen Jawa Tengah. J. Perikanan, 8492. 